\title{
Cytokeratin 5/6 Immunohistochemical Expression
}

National Cancer Institute

\section{Source}

National Cancer Institute. Cytokeratin 5/6 Immunohistochemical Expression. NCI

Thesaurus. Code C80497.

An immunohistochemical diagnostic test utilizing an antibody to detect both cytokeratin 5 and 6 in tissues. 